\title{
EDUCATION THROUGH EXCURSIONS IN THE FUNCTION OF SUSTAINABLE DEVELOPMENT OF TOURISM IN THE CASE OF NATIONAL PARK ĐERDAP
}

\author{
Sara Stanić Jovanović ${ }^{* 1}$, Milena Cvetković* \\ * Ph.D. students, University of Belgrade - Faculty of Geography, Belgrade
}

\begin{abstract}
Excursions represent specific aspects of tourist movement that are related to the traveling of a group of people, usually for fun but also for educational purposes, when it comes to pupils and students who are traveling. Creating thematic excursions in the territory of the national park Đerdap with special emphasis on the attractive parts of protected area of the national park, among which there are natural and anthropogenic tourist potentials, contributes to raising the level of awareness and knowledge of possibilities of sustainable development of tourism. The Đerdap Gorge, the Danube River, Lepenski vir, Golubac, the remains of Trajan's bridge, Trajan's board (tabula Traiana), the Roman limes, the preserved richness and diversity of flora and fauna, are just a part of the tourist attractive motives that fit excursion tourist product of the Đerdap National Park and thus attract visitors. Apart from developing interest in the protection of the environment and acquiring traveling habits, as well as introducing adequate ways of staying and behaving in the national park Đerdap, the participants in excursions educate themselves indirectly, through this type of traveling, about the values of the national park, as well as the importance of specific forms for the sustainable development of tourism in the territory of Đerdap.
\end{abstract}

Key words: excursions, tourism, Đerdap, sustainable, development

\section{Introduction}

Excursion tourist product is characterized by an intensive pace of touring the planned sites with a relatively short stay of the participants consider-

\footnotetext{
${ }^{1}$ Correspodence to: sara.stanic.zemun@gmail.com
} 
ing that the excursions last approximately two to three days. The demand for excursion tourist movements in the field of school and youth tourism is constant in the tourist market and the excursions represent at the same time a method of scientific cognition and immediate introduction of phenomena and objects in the nature. The Đerdap National Park, as the protected area of the Đerdap Gorge through which the Danube River flows and which has extremely diverse flora and fauna with plenty of endemics and rich cultural and historical heritage, has always been a challenge for all travelers as well as warriors, merchants and peacemakers. Đerdap or Danube's Iron Gate is a link between the upper and middle Danube region, as two important cultural and economic parts of Europe and for centuries, it has had a strategic position of great importance. It represents, above all, an interesting and unique excursion and tourist destination. Traveling Đerdap gives the participants an opportunity to meet various tourist motives and sites with a special emphasis on the sustainable tourism development with the same tourist destination.

\section{Conceptual definition of excursions}

In more relevant living languages of the world, the following phrases are reserved for the concept of excursions: in the English language, it is "excursion", in French it is "excursion", in German it is traditionally and more precisely "Schulausflug" and in Russian, it is "ekskursir". It is evident that the living languages today have kept, terminologically conceptual, Latin "excursion". Excursions represent one of specific forms of tourist movements and as such, they can be observed from the aspect of their great share in the tourist traffic of Serbia. Demand for such kind of tourist travels is constant which points out their economic importance. (Stanić Jovanović, 2015, Шабић и др., 2012, Стојимировић, 2008).

The word excursion stems from the Latin word "excursion" which in translation means a trip, short journey, traveling for fun (Vujaklija, 1970). It is connected to the concept of a group of people traveling, where the purpose of the trip is marked as educational or simply as spending their free time. Both the trip and excursion are often used as a complement during the long journey, a visit, or a stay in a specific destination (Štetić, 2003).

We often use the term "picnic" for popular trips in the nature while for a tour of the cultural heritage the term "excursion" is the most commonly used. Both terms are translated as outing or recreation (Garača, Obradović, 2006; Vujadinović et al., 2013). The same applies to the term tripper (a person 
who goes on a trip), which can be seen as picnicker as well as excursionist. The dictionary of foreign words explains the concept of excursions such as a trip, short journey, or traveling for fun (Klaić, Anić, Domović, 1999).

A similar term is the term picnic. In contemporary usage, picnic can be defined as a pleasure excursion whose main feature is a meal eaten outdoors, in the open space. The ideal venue for a picnic is a natural landscape, whether it is a city park, lake surroundings or an area by the river. The first use of the term picnic origins from 1692 in France, and describes a group of people who dined together in a restaurant, where they brought their own wine. The term has retained, for a long time,the connotation of common meal where everybody contributes with something. In English, the term first appeared in a letter from Lord Chesterfield from 1748. This interesting story says that after the French bourgeois revolution in 1789, going on a trip or a picnic in the Royal Parks (for the first time open to the public at that time), became a very popular activity among French citizens (Oxford English Dictionary, www.oed.com).

Excursions present group touring of attractive buildings and phenomena of a certain area as well as their professional and scientific understanding. According to its purpose, excursions can be divided into: tourist excursions, whose goals are recreational and entertaining and educational in general and school excursions that contribute to the realization of teaching programs relating to the natural and social content of a certain area (Rudić, 1999).

Excursions in the form of tourist traveling can be classified in several ways and using different criteria. Some of the most important criteria of classification are: the length of stay, type of transport, the number and age of its participants, the nationality of the participants, the characteristics of the excursion group, the nature of the trip, the size of the market space, the origin and method of organizing the excursion, type of tourist motive, the need for tourist movement, form of the excursion, the season, etc. (Stanić, 2010).

When it comes to age, excursions can be divided into: children excursions, which are organized solely for children usually the younger ones in kindergartens and preschools; school excursions, which represent trips where participants are usually school-age children and they can also be called pupil excursions; youth excursions involve the movements where the youth represents the participants and they are mostly teenagers; student excursions are those where the participants are students and which are most frequently organized for the collective of the same or several different universities; adult excursions present the excursions meant for the older participants and they can be organized within certain collectives but also regardless of them and 
retirement excursions which are organized for the retired people and they can also be called excursions of "the third age" (Stanić Jovanović 2015).

Excursion is a name used for pupil and student travels so it is about travels that are characterized by specific clientele. Unfortunately, nowadays in our country typical pupil excursions are increasingly giving way to trips consisting of a group of pupils simply coming to a place and staying there a couple of days taking two-three trips to theclose surroundings and returning home. The traditional specific form of educational work with its clear goals and objectives and transformation into predominantly recreational forms, lost almost all meaning. In addition, school trips should be significantly different from other tourist and recreational pupil travels. Primarily, theyshould becharacterized by program specificity: strictly defined itinerary containing primarily educational (acquisition of new theoretical knowledge or establishing the previously acquired knowledge in practice), followed by cultural and social (social activities, meeting new people), and then the recreational component in terms of leisure and entertainment (Štetić, 2003).

\section{Educational role of excursions}

Excursions present a special form of teaching outside the classroomfor the immediate study of one subject matter that cannot be successfully demonstratedin the classroom. In this respect, it is defined that excursion's goal should be determined on the basis of educational tasks of individual curricula; excursions should be made by going to valuable natural, cultural, historical and economic places; it is necessary to have more types of excursions with regard to the place, subjects, processing of lesson topics, duration and other criteria and based on the type and character of excursions, excursions should be made according to the adequate organization, planned and arranged so that their realization goes through certain stages or phases; to establish, in advance, adequate questions for the conversation regarding excursions; final and additional work after excursions; they should favorably influence the revival of pedagogical work, immediate experience and evidence as well as the development of curiosity, observation skills, desirable behavior in children and many other desirable personality traits (Encyclopedic Dictionary of Pedagogy, 1963).

In the Pedagogical Dictionary, the term excursion is dealt with conceptually without the attributive supplements (for example pupil, educational, school excursion, etc.) and as a special form of educational work or activity. 
When specifying the essential characteristics of the form or method of work, it was pointed out that the excursions allow participants to explore objects and phenomena in the natural environment and natural conditions, but not in a systematic way as it is accomplished in the classroom. The wealth of impressions and materials from excursions easily draws participants' attention from the objective to unimportant things, and the excursions take up a lot of time (Pedagogical Dictionary I, 1967).

An excursion represents a form of educational work, which contributes to achieving the plans, programs and educational goals that are accomplishedoutside the buildings of educational institutions for a period of one to three days per year, according to age and curriculum for excursions. The aim of an excursion is directly exploring of phenomena and relationships in the natural and social environment, exploring the cultural, historical and spiritual heritage and economic achievements. Excursion contentsare realized based on the curriculum of educational work and pre-school programs and they are an integral part of the annual curriculum. The program of excursions includes: educational goals and objectives, contents that help to achieve set goals; planned coverage of participants; holders of planned content and activities; duration; travel directions; technical organization and funding (Ordinance on amending the Ordinance on the curriculum of primary education, 2009).

Excursions as a method of scientific cognition and a form of field lessons represents an unavoidable segment of primary and high school curricula and it appears more frequently in the educational institutions' offer which makes their plans more popular. Excursions must have a clearly set goal and the organized trip must be carried out according to the plan and program. In regards to that, excursions present a tourist travel that can be made in order to realize the theoretical part of educational work by using different didactic principles based on direct contact with buildings, phenomena and processes in the area as well as detecting their mutual connections and patterns. The task of excursions is for the participants to observe the elements of the socalled real statein certain scientific and educational areas directly in the area and thus gain a clear perception (Romelić, Tomić, 1999).

The Institute for Improvement of Education in Belgrade formulates the educational tasks of excursions as follows:

- that the participants develop the ability to monitor, observe and perceive objects, buildings and phenomena, to analyze and understand their mutual relations and connections both in nature and in human society; 
- to contribute to deepening, broadening and enriching experiences, to encourage and be interested in new findings that link theory with practice, to encourage participants to actively participate and contribute to the development of society;

- to develop patriotism and nurture solidarity, humanism, friendship, devotion,collective spirit, life optimism and a real understanding of life;

- to contribute to a better and more versatile perception of character as well as establishing closer, more direct mutual relations in a group;

- to encouragethe participants to develop their sense and desire for active participation in socially beneficial work, to know how to assess the true value of the work, to pursue avocation more confidently, to nurture persistence and perseverance, habits, responsibility, accuracy and values in work;

- to develop a sense of beauty, to awaken the love of nature, natural beauty, as well as the achievements of material and spiritual culture of humanity, to encourage artistic expression;

- to recognize the role of a man and his influence on the geographical environment and opportunity for its protection, and the ability to contribute to education and training (Pupil excursions, Tours and visits, 1977).

It is important to point out that excursions should not be considered a method (because during excursions, several methods are used such as observation, demonstration, explanation, practical work, etc.) but a form of teaching. An important characteristic of excursions is the fact that they substitute demonstrational experiments; that children are familiar with technological processes of work and man's working functions and excursions evoke and create various positive feelings. In subsequently published sources, it is said that the excursion is a form of teaching in different places away from school buildings for the immediate study of teaching content at adequate primary sources, and which otherwise would not be successfully studied in the classroom at secondary sources (Pedagogical encyclopedia I, 1989).

As opposed to previous considerations, here it is pointed out that during excursions we should take into account the proper shift between the work and the rest. It is important that during excursions participants learn a lot and that they have both educational and health significance. The isolated term excursion is not defined here but other terms are connected with it such as "educational", "school", "pupil" and other terms and so whole linguistic syntagms 
Education Through Excursions in the Function of Sustainable Development of Tourism in the Case of National Park Đerdap

are defined ("educational excursion", "school excursion", "pupil excursion", etc.). Therefore, excursions are not considered a general form of educational work, but a form of teaching work or an organized form of teaching. Thus, an excursion is a form of pedagogical work program for the immediate study of educational content at adequate sources that could not be successfully studied in the context of everyday educational and pedagogical forms. This allows organizing a wider and more gradual observation and study of objects, phenomena, processes and patterns in natural or real (industrial) conditions, as well as visits to factories, museums, exhibitions, historical and cultural monuments, various institutions, etc. (Pedagogical Lexicon, 1996).

Direct contact with the natural and anthropogenic values, as well as with the relevant attractive locations, stimulates and causes aesthetic and emotional experience. Aesthetic education (identification, assessment, experiencing and creating something beautiful) is an important component of comprehensively developed personality.In the sphere of fieldwork, there isa direct encounter with the aesthetic attributes of natural and anthropogenic tourist values. The participants can notice and assess them in the best way, as well as experience them emotionally, precisely during excursions. Past experience has shown that excursions, as a form of tourist movements, are the largest contributor to the development of specific-logical thinking and visual memory. Although the meaning and goals of children's excursion are clear, since they are determined by criteria in the field of educational activities due to certain peculiarities of excursion movements, many tourism theorists do not include them in the category of tourist movements.On the other hand, there are numerous facts that indicate that the phase of organizing excursions includes many components precisely in the field of travel industry (Romelić, Tomić, 1999).

Thematic excursions that children go to, in protected natural areas, can represent an excellent way of educational methods that introduce children to the natural environment, the elements and the basic laws of nature. In this way, it is possible to bring children closer to the growing problem of environmental pollution through a game, during the journey and at the destination. Visiting a national park, natural park, landscapes of exceptional characteristics, nature reserves or protected monuments of nature, children, as participants of excursion travels, are introduced tothe importance of variety and of preserving the natural heritage of a particular region. Attractive, aesthetic and curious characteristics of the natural environment, as well as the diversity of flora and fauna, contribute to drawing attention of children and facilitate learning about how to behave in nature so that we do not jeop- 
ardize it. In this way, the excursionsbecome very important as a method of direct education to preserve the environment (Stanić Jovanović, 2015).

\section{Đerdap National Park (Serbia)}

The Đerdap National Park is located in the southeastern Europe, on the border with Romania. Along the Danube's right bank, on a 100-kilometer stretch from Golubac Fort to castrum Diana Karataš, the National Park encompasses a narrow forested mountain area, two to eight kilometers in width, reaching 50 to 800 meters above sea level. There are three primary entrances to Đerdap National Park, two on Đerdap main road M 25 near Golubac and Diana Karataš, and another one on the R 106 regional road Porečki Most-Klokočevac. The National Park is open to visitors all year round and it can be toured by cruising on the Danube, or along Đerdap main road, as well as down biking and hiking trails, with adherence to the Park's rulebook and the rules of conduct in protected areas. A combination of weather and nature of the mainland and water, biggest national park in Serbia, Đerdap National Park, is located in the northeastern part of Serbia, on the very border with Romania (www.npdjerdap.org/29.06.2016.).

The Đerdap National Park is located in the northeastern part of Serbia, on the border with Romania and spatially it covers the narrow corridor of the Đerdap Gorge, i.e. its right valley slope and coastal sector of the Danube from Golubac to Karataš, at a length of almost $100 \mathrm{~km}$. It was placed under protection in 1974, it covers an area of $637.68 \mathrm{~km}^{2}$ and territory of three municipalities, Golubac, Majdanpek and Kladovo (Вујадиновић и др., 2012.; Nikolić, 2006; Institute of Architecture and Urban and Spatial Planning of Serbia, 2013).

Đerdap gorge was established as a national park in 1974. The area is mostly covered by forest (ca 64\%). The park covers terrestrial and riverside parts, and consists of three canyon-gorge valleys (Golubačka, GospodjinVir and Mali iVeliki Kazan) and three basins (Ljupkovska, Donjomilanovačka and Orsavska). The canyons cut through the limestone rocks of the South-Carpathians (Шабић и Вујадиновић, 2014.; Papp, В., P. Erzberger, and M. Sabovljević, 2006).

Due to specific conditions of climate, relief and soils, and the Hydrology of the Danube canyon in particular, the ecosystems of the park show refugial characteristics with a high percentage of relict species and communities, one of the most precious peculiarities of this region (Stevanović and Vasić, 1995). 
Education Through Excursions in the Function of Sustainable Development of Tourism in the Case of National Park Đerdap

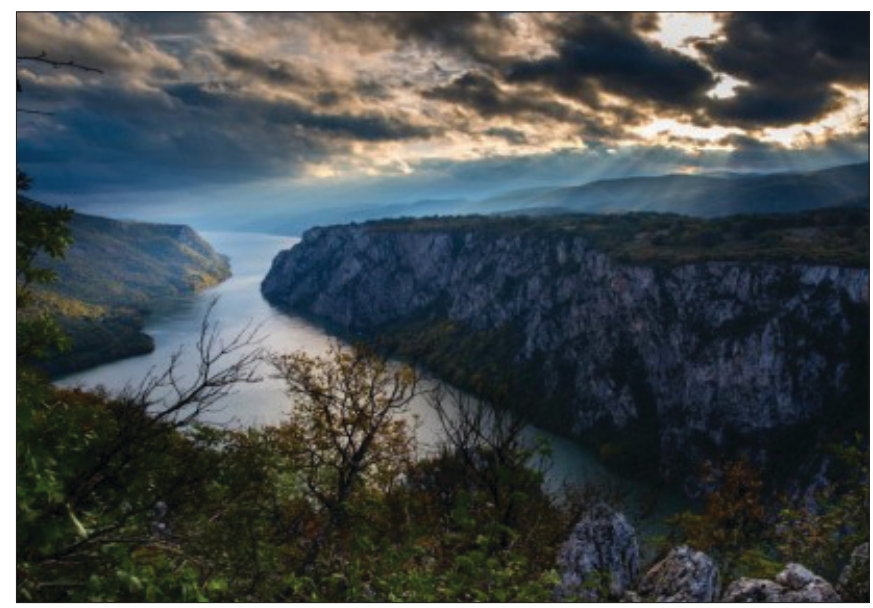

Fugure 1 - The National park Đerdap viewpoint Source: www.npdjerdap.org

Zones with various regimes of protecting objects of nature, cultural monuments, fauna and vegetation of relict species, confirming the evolution of vegetation series ever since our creation up to modern time, spread across the surface of 637.68 square meters along the right bank of the Danube, starting from Golubac all the way to Karataš at Kladovo. The Đerdap National Park is also known as a riverside national park, considering that an important part of Đerdap consists of the Danube, and the biggest and longest breakthrough gorge in Europe, wondrous Iron Gate, wild botanical garden and largest European archeological museum in nature. The Đerdap Gorge and the natural area surrounding the gorge, as well as the environment, with exceptional cultural and historical values, pertinent natural ecosystems of great value and rare quality, judging by their content; objects of original flora and fauna and well preserved forests with natural growth and remarkable appearance. Basic natural phenomenon of the Đerdap National Park area is the grandiose Đerdap Gorge, the longest and largest breakthrough gorge in Europe. Specific historical development, very favourable Đerdap climate, complex network of gorges, canyons and deep ravines, distinguish this area as the unique European reservation of tertiary flora, vegetation and fauna (www.npdjerdap.org/29.06.2016.). 


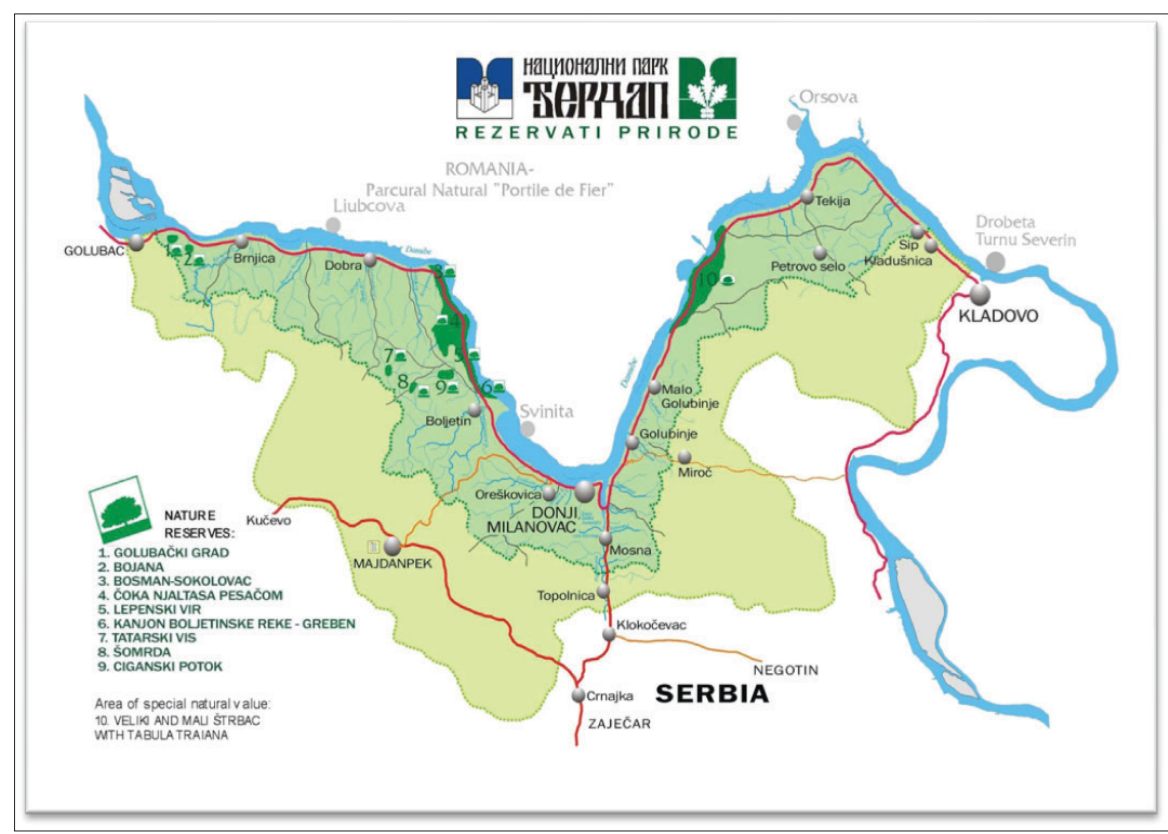

Figure 2 - Djerdap NP in Serbia and the 3 zones of protection marked in green Source: www.npdjerdap.org

The greatest hydrological characteristic of the National Park Đerdap is a lake formed by damming of the Danube for the production of electricity and improving conditions of the navigation. The construction of dams and the lake formation improved conditions of navigation, because the lake water sinks underwater rocks, whirlpools and giant pots. Water bath in Đerdap Lake is possible in June, July, August and September according to the average monthly temperature (Stanković, 2003).

Thanks to the specific historical development, favourable climate and complex geomorphologic characteristics, the area of Đerdap today represents a unique nature reserve of tertiary flora and fauna. The territory of the National Park is represented by over 1100 plant species (of which 43 species are strictly protected and 124 are protected) and over 150 species of birds. In addition to diversity, a marked endemic and relict character characterizes flora and fauna of this area. Due to the favourable conditions of life, man was constantly present in this area, as evidenced by numerous archaeological sites and cultural and historical monuments ("Lepenski Vir", Castrum "Diana", fortresses "Golubac" and "Fetislam", "Tabula Traiana", 
remains of "Trajan's Bridge" and Castrum "Pontes", etc.). Thanks to all of the above, the National Park "Đerdap" is abundant in representative and attractive natural and cultural values, and having a special, protected status, the ideas of achieving sustainable tourism development in the national park have a realistic basis and deserve to be considered professionally in the future (Brankov, Jovičić, and Milijašević, 2015).

Đerdap flora is not only known by its versatility and abundance, but also by its exceptional relict character. Regarding the elements of woody flora, there are Turkish hazel, hackberry, walnut, lilac, silver linden, field maple, downy oak, and special value is held by forest and shrub communities. Versatility of habitat and communities also reflects on fauna, which, like flora, is characterized by its relict properties. In this area, you can find deer, lynx, wolf, jackal, golden eagle, Eurasian eagle-owl, black stork and many other species. Very favourable living conditions have been the reason for permanent human presence which is proved by a number of archeological findings and cultural and historical monuments, such as: 'Lepenskivir' settlement, archeological sites such as Diana, Golubac ancient city, remains of Trajan's road, Tabula Traiana, Roman Limes, various forecastles, up to preserved samples of folk Slavic architecture (www.npdjerdap.org/29.06.2016.).

A particular influence on the development and changes in the Đerdap area nowadays is carried out by the dam construction (1964-1971). The negative effects of the construction unfortunately are a large number of submerged archaeological sites and cultural and natural resources as well as the relocation of several villages. Planned built new settlements on the shores of the lake have preserved their names and the people and follow their traditions in the new conditions (Grupa autora, 2010).

\section{Education through excursions in the function of sustainable development of tourism in the case of national park Đerdap}

The Đerdap National Parkwith the natural area along the gorge, as well as spatial units, is an interesting destination for sustainable tourism development in the Europe tourism market, because of its exceptional cultural and historical values, beside significant natural ecosystems in composition of exceptional value and rarity. In its overall tourist offer, Đerdap represents a separate and complete travel unit which is in many ways unique in Europe and worldwide. Đerdap gorge offers the visitors rare, unique and attractive tourist facilities throughout the year due to its morphological and hydrographic 
characteristics, attractive Danube landscapes, which are based not only on relief diversity but also on the wealth of cultural and historical heritage and the very specific ethnological features of the region. Đerdap, as a tourist destination, because of unity of its extraordinary tourism potentials (plenty of geological and morphological motives, flora and fauna wealth, valuable cultural and historical heritage of the past and specific ethnological heritage areas), is a united and above all unique region offer of the Danube countries. On the territory of the National Park there are nine regulated and marked walking trails of various lengths, passing through attractive landscapes andnature that often end at the lookout. These trails are the following: River Canyon Brnjica, Bosman - Sokolovac, Gypsy stream - Šomrdski stone, River Canyon Boljeton - Reef, Lake BaltualuŠontu - Glavica, Cave Gradašnica, Buronov sink, Large and Small Štrbac and Kovilovo. The Iron Gate is one of the 35 identified IBA (Important Bird Areas) areas in Serbia. Three species of birds make the Đerdap area internationally important: pygmy cormorant, lesser-spotted eagle and miniature eagle. The bike path that connects the 6 Euro Velo Atlantic and the Black Sea is passing through the National Park in the length of 100 kilometers, which is why this protected area is registered in the cycling map of Europe. The Danube route is one of the most popular cycling routes in Europe. A system of designation for Danube cycling route (DBR) that runs through Serbia has unique characteristics and design different fromthat in other Danube countries, and that is why it is original on a European scale. Events are an important component of integral tourist product and content elements of tourist stay,thus the hunting event "Hunter's encounter with a wolf" in Dobra, ethnic heritage festivals such as the "Lilac fest" on the Miroc or "Ethno Festival" in Golubac, then "Gold plop of Đerdap" in Tekija, represent only a part of the tourism-sport-culture and entertainment-events that bring together a large number of participants and visitors (Stanić, 2012).

In this way, schools in nature, health paths, photo safari or boat trips, are together representing some of the integral and complementary aspects of sustainable tourism development products in the national park Đerdap area. The largest number of visitors, in terms of domestic visitors to the Iron Gate comes from Belgrade, Vojvodina, Šumadija, Morava and Eastern Serbia. The peak time is in May, June, September and October. In recent years, the growing interest of foreign tourists in the Iron Gate area is noted. Setting Đerdap as a major excursion destination in the Danube region may result in an increase in the demand of the international tourist market around the world and it may attract a lot of tourists. Joint marketing, promotion and management of tourist destinations in the Danube region will contribute to the 
Education Through Excursions in the Function of Sustainable Development of Tourism in the Case of National Park Đerdap

development of the excursion destination of Đerdap as a unique offer at European and world tourist market. Active excursions and weekend tours can be developed in the gorge, in the national park and Đerdap Lake in different forms and through different means of transportation (car, bicycle, boat, bus). Intensifying the promotion of active excursion tourism contributes to raising awareness of healthy lifestyle as well as the expansion of educational and cultural level of the tourist clientele (Stanić, Šimičević, Pavlović, 2011).

In the age of restriction or limitation of mass tourism in order to preserve resources for future generations while emphasizing the importance of sustainable tourism development, the importance of specific forms of relief and recreational facilities of every kind within the rural tourism destination for their further development is somewhat neglected (Štetić, Šimičević, Stanić, 2011).

The concept of sustainable tourism development, which implies a rational, complementary, coordinated and environmentally sustainable use of resources of the environment, is one of the most important routes of directing the development of any tourist destination. Offer based on a stay in ecologically clean environment with the production of ecologically clean food, represents an increasingly important trend in demand on the global tourism market. Tourist destinations that are characterized by a wealth of natural and anthropogenic potentials in the immediate environment of the urban industrial centers find their opportunity in planning for sustainable tourism development. Modern tourists expect and require tourist programs through which they participate, by travelling, in the economic, social, and cultural development of local communities and contribute to the preservation of natural resources of the environment. Expanding environmental awareness, tourism experiences a metamorphosis, and polluted and over-commercialized tourist destinations cease to be within the interest range of modern tourists (Štetić, Stanić, Šimičević, 2011).

Excursion tourism in Serbia in recent decades in its specific areas, such as youth and school tourism, has seen continued tourist traffic despite a series of negative, limiting factors. These are organizational deficiencies, obsolescence of offers, inadequacy of infrastructure in the country and other weaknesses of subjective nature, in addition to objective difficulties related to the political, social and economic instability in Serbia in the past. Due to the global economic crisis, with some negative aspects of civilization (noise, stress, fatigue, unhealthy life, fast pace of life, etc.), excursion movements that follow the world trend of taking more short breaks during the year, also represents an excellent solution (Stanić, Šimičević, Pavlović, 2011). 
Youth and school tourism are well developed in the area because a large number of young people (participating in school trips, excursions and classes in nature) come to visit the Đerdap area. This type of tourism is in addition particularly interesting to primary and secondary school students and to students of tourism, geography, biology, forestry, geology, hydraulics, transport, history, art and other groups. Besides the selection of recreational classes for children, (children in kindergartens and preschools) Đerdap is a tourist destination for group travels of retirees or other closed, homogeneous groups like the collectives of different companies, in terms of cultural movements. Excursion tourism in Đerdap in the form of organizing individual and group tours that include visits to many cultural and historical monuments and nature reserves is very well developed. In addition to the aforementioned excursion sites, Đerdap attractions include the following: cave tours ("Rajko's cave", "Gradašnica", "Dubočka", "Ceremošnja”, "Ravništarka"); nature monuments ("Vratna gates", "Valjaprerast"); visit to Đerdap I Hydroelectric Power Station; Kladovo Fish Combine; archaeological sites (Viminacium, Felix Romuliana), fortresses (Fetislam, Ram), monasteries (Vratna, Koroglaš, Bukovo, Gornjak, Vitovnica, Tumane, Zaova); locations on the wine route (Rajačke, Rogljevske, Smeovačke and Stubicke wine cellars). That is why the excursion tourist area of the Đerdap attractions expand and complement in both content and quality. Possible excursion movement in the Đerdap area and environment are determined by the use of certain types of vehicles-bus, car, boat, bicycle (Stanić, 2012).

\section{Conclusion}

Đerdap area is particularly interesting in the domain of school trips where it appears as the most wanted destination. It is also significant when it comes to boat cruises as a supplement of the program and as various types of individual and group excursions, both domestic and international. Activities and projects of the Strategy for the Danube region, the promotion of tourism resources in the Iron Gate, changes in the global tourism market demand and the strengthening of new types of tourism developments aimed at sustainable development and protection of natural and cultural heritage, contributing to the positioning of tourists destination Iron Gate as a unique excursion destination in European tourism market.

Creation and realization of excursions in the area of the national park Djerdap with an emphasis on sustainable tourism development contribute 
to raising awareness of the participants in the excursion and their education. Throughout the journey and direct introduction and a tour of natural, cultural and historical sites in the area of the national park Djerdap, excursion participants gain adventures, experiences and memories, as well as continuous education, which remains deeply in their consciousness.Consequently, the authors of this paper believe that education is an important and unavoidable segment of excursions in terms of sustainable tourism development. In addition,thematic excursions in the area of the national park Djerdap in Serbia, with an emphasis on sustainable tourism development, have the option, in their basis, of training which is why it is necessary to create and implement them on the tourism market.

\section{Reference}

Brankov, J., Jovičić, D. and Milijašević, D., (2015). Sustainable Tourism in National Park "Đerdap", Serbia-Attitudes of Local Population. Journal of the Geographical Institute "Jovan Cvijić" SASA, 65(2), 183-199.

Grupa autora (1963). Enciklopedijski rječnik pedagogije, Matica Hrvatska, Zagreb.

Grupa autora (1967). Pedagoški rečnik I, Zavod za izdavanje udžbenika SR Srbije, Beograd.

Grupa autora (1989). Pedagoška enciklopedija I, Zavod za učenike i nastavna sredstva, Beograd.

Grupa autora (2010). Predlog plana upravljanja područja Nacionalnog parka Đerdap (2011-2020 god.), Javno preduzeće „Nacionalni park Đerdap“, Donji Milanovac.

Institute of Architecture and Urban and Spatial Planning of Serbia (2013). Spatial Plan for the Special Purpose Area of the National Park "Đerdap" (in Serbian). Belgrade.

Klaić, N., Anić, Š. i Domović, Ž. (1999). Rječnik stranih riječi, Sani-Plus, Zagreb.

Nikolić, S., (2006). Turizam u zaštićenim prirodnim dobrima. Beograd: Zavod za zaštitu prirode.

Oxford English Dictionary, www.oed.com/21.11.2014.

Papp, B., Erzberger, P. and Sabovljevic M. (2006). “Contribution to the bryophyte flora of the Đerdap National Park (E Serbia)." Studia bot. Hung, 37, 131-144. 
Potkonjak, N. M. i dr. (1996). Pedagoški leksikon, Zavod za udžbenike i nastavna sredstva, Beograd.

Pravilnik o izmeni Pravilnika o nastavnom planu i programu osnovnog obrazovanja i vaspitanja, „Sl. glasnik RS Prosvetni glasnik“, br. 1/2009.

Romelić, J. i Tomić, P. (1999). Problem usaglašavanja organizacionih i didaktičkih normi nastavnih ekskurzija i poslovne politike putničkih agencija, Turizam - časopis Instituta za geografiju, Novi Sad.

Rudić, V. (1999). Metodika nastave geografije, Geografski fakultet, Univerzitet u Beogradu, Beograd.

Stanković, S. (2003). Nacionalni Park Đerdap - Polifunkcionalna turistička regija, Glasnik Srpskog geografskog društva, 83(1), 43-56.

Stanić, S., (2010). Anthropogenic Heritage of National Park Đerdap - as an Important Part of Tourism Development Strategy in Serbia, Danube Strategy-Strategic Significance for Serbia, The Institute of International Politics and Economics, Belgrade, pp 274-289.

Stanić, S., (2010). Značaj i organizacija izletničkog turizma u turističkoj ponudi Srbije, Master rad, Geografski fakultet, Univerzitet u Beogradu, Katedra za turizmologiju, Beograd.

Stanić, S., Šimičević, D. and Pavlović, S. (2011). Đerdap as an Excursion Destination - A Unique Offer in the European Tourism Market, Collection of Papers from The Conference - Contemporary Trends in Tourism and Hospitality - Via Danube, the Main Street of Europe, University of Novi Sad, Faculty of Science, Department of Geography, Tourism and Hotel Management, Novi Sad, 29-38.

Stanić Jovanović, S. (2015). Edukativna uloga ekskurzionog turizma, Turističko poslovanje, Visoka turistička škola strukovnih studija, Beograd, 15, 125-133.

Stevanović, V. and Vasić, V. (eds) (1995). Biodiversity of Yugoslavia with survey of internationally significant species. Bioloski fakultet Univerziteta u Beogradu, Ecolobri, Beograd

Štetić, S. (2003). Vodička služba u turizmu, autorsko izdanje, Beograd.

Štetić, S., Šimičević, D. i Stanić, S., (2011). Rekreativni prostori u ruralnim područjima Srbije i njihova uloga u održivom razvoju, Zbornik radova, Sedma regionalna konferencija: "Životna sredina ka Evropi", Ruralni i održivi razvoj planina, Beograd. 
Education Through Excursions in the Function of Sustainable Development of Tourism in the Case of National Park Đerdap

Štetić. S., Stanić, S. i Šimičević, D. (2011). Mogući pravci održivog razvoja turizma planine Rudnik, Zbornik radova, Sedma regionalna konferencija: "Zivotna sredina ka Evropi", Ruralni i održivi razvoj planina, Beograd.

Vujadinović, S., Šabić, D., Joksimović, M., Golić, R., Gajić, M., Živković, Lj. and Milinčić, M. (2013). Possibilities for Mountain-based Adventure Tourism: the Case of Serbia?, Bulletin of Geography: Socio-economic Series, 19, 99-111.

Вујадиновић, С., Гајић, М., Шабић, Д. и Милинчић, М. (2012). Туризам као компонента развоја градских насеља пограничног простора Србије и Бугарске, У Шећеров, В., Радосављевић, 3., Ђорђевић, А. и Марић, М. (ур.): Планска и нормативна заштита простора Србије, АППС, Географски факултет у Београду, Београд, 391-402.

Стојимировић, С. (2008). Саобраћај у функцији развоја Дунавског кључа. Зборник радова - Географоски факултет Универзитета у Београду, 56, 143-150.

Шабић, Д., Јоксимовић, М., Михајловић, Б. и Самарџић, И. (2012). City Break туризам - одрживи ресурс шумадијских градова: пример Београда, У Нешковић, С. (ур.): Друштвено-економски развој Србије са акцентом на Шумадију и Крагујевац, Едиција: Безбедност у постмодерном амбијенту, Центар за стратешка истраживања националне безбедности, Београд, 15, 295-306.

Шабић, Д. и Вујадиновић, С. (2014). Регионална географија Европе, прво издање, Универзитет у Београду - Географски факултет, Београд, 1-429.

www.npdjerdap.org/29.06.2016. 